\title{
先天性心疾患における低侵襲アプローチ（MICS）の 標準術式としての妥当性
}

\begin{abstract}
西宏之西垣恭一久米庸一宮本勝彦
小正中皮膚切開, 胸骨部分正中切開による低侵襲アプローチ（MICS）の標準術式としての妥当性について, レジデント群（R 群）とスタッフ群（S 群）に分類して検討を行った。過去 3 年に当科で施行した MICSに よる心房中隔欠損（ASD）42 例（R 群 15 例， S 群 27 例)，心室中隔欠損（VSD）47 例（R 群 6 例, S 群 41 例）に関して, 各項目（手術時間，体外循環時間，心停止（または心室細動）時間, 術後挿管時間, ICU 滞在日数, 術後入院日数, 術後ドレーン排液量, 術後最高 CRP 值, 術後最高白血球数, 皮膚切開長 $(\mathrm{cm}) /$ 身長 $(\mathbf{m}))$ について比較検討した。手術時間，体外循環時間，VSD の大動脈遮断時間は S 群が有意に低値 であった $(\boldsymbol{p}<0.05)$ が，他の因子に関しては両群間に有意差を認めなかった。 小皮膚切開，胸骨部分正中 切開による MICS は ASD, VSD において時間因子以外は術者による術後経過の差を認めず，一部の症例を 除けば標準術式として妥当であると思われた。，日心外会誌 31 巻 1 号：40-44（2002）

Keywords：胸骨部分正中切開, MICS, 標準術式
\end{abstract}

\begin{abstract}
Is Minimally Invasive Cardiac Surgery for Congenital Heart Defects Reasonable as a Standard Operation?

Hiroyuki Nishi, Kyoichi Nishigaki, Yoichi Kume and Katsuhiko Miyamoto (Department of Pediatric Cardiovascular Surgery, Osaka City General Hospital, Osaka, Japan)

Minimally invasive cardiac surgery (MICS) has been developed to offer patients the benefits of open heart operations with limited skin incision, but this procedure tends to be more difficult than conventional methods. We tried to evaluate whether MICS would be reasonable as a standard operation for congenital heart defects. From August 1997 to March 2000, 42 patients with atrial septal defects (ASD) and 47 patients with ventricular septal defects (VSD) underwent total repair by the minimal skin incision and lower partial median sternotomy. Fifteen ASD patients and 6 VSD patients were enrolled by residents (resident group). Twenty-seven ASD patients and 41 VSD patients were treated by leading surgeons (staff group). We compared the clinical course of the patients between resident and staff groups. Operative time, bypass time and cardiac arrest time (VSD) of the staff group were clearly shorter than those of the resident group $(p<$ $0.05)$. Other clinical course parameters of the two groups showed no significant difference. The results of this study indicate that MICS for ASD and VSD is reasonable as a standard operation because there was no significant difference of postoperative clinical course except the time required for the operation. Jpn. J. Cardiovasc. Surg. 31 : 40-44 (2002)
\end{abstract}

近年，小児開心術に扔いて，小正中皮膚切開，胸骨部分 正中切開による minimally invasive cardiac surgery (MICS) が導入 ${ }^{1)}$ れ，美容上の利点など患者の QOL 向 上に寄与する点が多く，当施設でも積極的に採用してい る.この術式は対象疾患として心房中隔欠損 (ASD) や 心室中隔欠損（VSD）などの単純心奇形が多いが, 狭い 術野のため若干手技が困難となり，一部の熟練した術者の みしか行えない傾向がある，そこで，今回われわれは，同 術式がレジデントでも施行可能な標準術式として妥当であ るかについて検討したので報告する。

2001 年 2 月 14 日受付, 2001 年 6 月 28 日採用 大阪市立総合医療センター小児心臟血管外科〜 534-0021 大 阪市都島区都島本通 2-13-22

\section{対象および方法}

1997 年 8 月〜2000 年 3 月に当科で施行した MICS によ る ASD 42 例, VSD 47 例を対象とした. 男児 38 例, 女 児 51 例, 年齢は 3 力月 17.5 歳 (平均 $4.1 \pm 3.7$ 歳), 身 長は54.5 162.6 cm (平均 $94.3 \pm 26.0 \mathrm{~cm}$ ), 体重は $4.5 \sim 50.2 \mathrm{~kg}$ (平均 $15.3 \pm 10.0 \mathrm{~kg}$ ) であった. ASD, $\mathrm{VSD}$ 症例それぞれをレジデント群（R 群）とスタッフ群 (S 群) に分類 (表 1). 手術時間, 体外循環時間, 心停止 （または心室細動）時間, 術後挿管時間, ICU 滞在日数, 術後入院日数, 術後ドレーン排液量, 術後最高 $\mathrm{CRP}$ 值, 術後最高白血球数, 皮膚切開長 $(\mathrm{cm}) /$ 身長 $(\mathrm{m})$ につき 比較検討した。

すべての表示は平均士標準偏差で行い，有意差検定には 
$t$ 検定， $\chi^{2}$ 検定を用いて， $p<0.05$ を有意差ありとした。

手術手技：仰臥位とし，皮膚切開は乳頭腺の高さより 1 $\mathrm{cm}$ 頭側以下から剣状突起下緑までの正中切開で, 長さ （皮膚切開長 $(\mathrm{cm}) /$ 身長 $(\mathrm{m})$ ) は 6.0 を目安とした. 胸 骨は体部のみの切開とした。心膜を尾側につりあげ, 大動 脈基部を尾側に毫引して送血管を挿入。上大静脈（場合に より右心耳）と下大静脈にそれぞれ巾着縫合をかけて脱血 管を挿入し，上下大静脈にテーピングを行った。ASD は 人為的心室細動, VSD は大動脈遮断下に心内修復術を施 行した。心筋保護液は上行大動脈から順行性に注入した。 左心系からの空気抜きは head down position 下に心筋保 護液の注入ルートからできるだけ長く行い, 必要により経 右室的に行った。開胸器, 送脱血管などの手術器具は通常 用いているものを使用した。なお， R 群の手術は十分な修 練を積んだ $\mathrm{S}$ 群の指導のもと行われた。

\section{結果}

両群間の患者背景には有意差を認めなかった（表 2) が，若干スタッフ群の症例のほうが年齢，身長，体重が小 さい傾向にあった．肺高血圧症例は有意にスタッフ群が多 く, 乳児の肺高血圧症例はレジデント群には 1 例もなかっ た. 合併症は S 群の VSDの 1 例に一過性の痙攣発作を認 めたが, 全例元気に退院した。胸骨全正中切開にコンバー トした症例は 1 例もなかった。

手術時間, 体外循環時間, 大動脈遮断（心房細動）時間

表 1 レジデント群とスタッフ群

\begin{tabular}{ccc}
\hline & レジデント群 $(\mathrm{R}$ 群 $)$ & スタッフ群 $(\mathrm{S}$ 群 $)$ \\
\hline $\mathrm{ASD}$ & 15 例 & 27 例 \\
$\mathrm{VSD}$ & 6 例 & 41 例 \\
\hline
\end{tabular}

は，それぞれ $\mathrm{ASD}$ では $\mathrm{S}$ 群 $100 \pm 17$ 分（75〜140 分）,

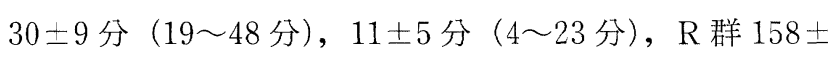
41 分 (95〜225 分), $42 \pm 13$ 分 (30 78 分), $10 \pm 4$ 分 (4〜11 分). VSD では S 群 $128 \pm 36$ 分 (95〜290 分), $53 \pm 19$ 分 (33〜139 分), $22 \pm 7$ 分 (12 48 分), R 群 $199 \pm 41$ 分 (150 265 分), $90 \pm 36$ 分 (69 164 分), $35 \pm$ 17 分 (18 68 分). ASD の心房細動時間以外は S 群が有 意に（ $p<0.05 ）$ 低值であった（図 1$)$. 術後扦管時間, ICU 滞在日数, 術後入院日数については, ASD では S 群

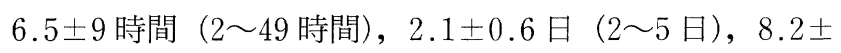
6.5 日（6４0日)， $R$ 群 $4.9 \pm 4.4$ 時間（1１8 時間）,

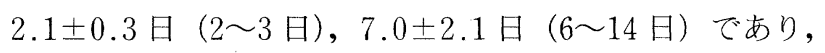

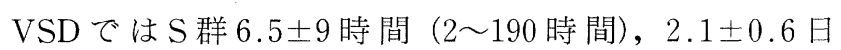
(2〜12 日), $8.2 \pm 6.5$ 日 (6〜30日), $R$ 群 $4.9 \pm 4.4$ 時間 ( $2 \sim 19$ 時間), $2.1 \pm 0.3$ 日 ( $2 \sim 4$ 日), $7.0 \pm 2.1$ 日（ $5 \sim 7$ 日）で両群間に有意差を認めなかった（図2). 術後ド レーン排液量, 術後最高 $\mathrm{CRP}$ 值, 術後最高白血球数, 皮 膚切開長 $(\mathrm{cm}) /$ 身長 $(\mathrm{m})$ に関しても両群間に有意差を 認めなかった（図 $3 ， 4)$.

\section{考察}

近年, 低侵襲手術が外科の各領域で普及しており，心蔵 血管外科の分野でも minimally invasive cardiac surgery (MICS) として人工心肺を用いない心拍動下冠動脈バイ パス術2) や皮膚切開を縮小化する各種の術式 ${ }^{1,3 \sim 6)}$ が報告さ れている. 小児心臟外科領域では, 主として小正中皮膚切 開, 胸骨部分正中切開による開心術が単純な心奇形に対し て行われており ${ }^{1)}$, 従来の術式と比較して遜色ない方法と して報告》さされている.これら MICSの対象となる疾患 は比較的単純な心奇形が多い。しかし, 一般的には低侵襲

表 2 両群間の患者背景

\begin{tabular}{|c|c|c|c|c|c|c|}
\hline & \multicolumn{3}{|c|}{ ASD } & \multicolumn{3}{|c|}{ VSD } \\
\hline & $\mathrm{R}$ 群 $(n=15)$ & $\mathrm{S}$ 群 $(n=27)$ & & $\mathrm{R}$ 群 $(n=6)$ & $\mathrm{S}$ 群 $(n=41)$ & \\
\hline 年歯令（力月） & $\begin{array}{c}95 \pm 58 \\
(15 \sim 210)\end{array}$ & $\begin{array}{l}73 \pm 38 \\
(8 \sim 162)\end{array}$ & n.s. & $\begin{array}{l}34 \pm 20 \\
(9 \sim 61)\end{array}$ & $\begin{array}{l}20 \pm 18 \\
(3 \sim 77)\end{array}$ & n.s. \\
\hline 体重（kg） & $\begin{array}{l}25.1 \pm 13.4 \\
(6.8 \sim 50.2)\end{array}$ & $\begin{array}{l}20.0 \pm 10.4 \\
(4.7 \sim 49.1)\end{array}$ & n.s. & $\begin{array}{l}11.5 \pm 3.3 \\
(7.5 \sim 15.5)\end{array}$ & $\begin{array}{c}9.0 \pm 4.0 \\
(4.5 \sim 19.8)\end{array}$ & n.s. \\
\hline 身長（cm） & $\begin{array}{l}118 \pm 30 \\
(64 \sim 163)\end{array}$ & $\begin{array}{l}109 \pm 21 \\
(60 \sim 154)\end{array}$ & n.s. & $\begin{array}{c}87 \pm 13 \\
(70 \sim 104)\end{array}$ & $\begin{array}{l}77 \pm 14 \\
(55 \sim 111)\end{array}$ & n.s. \\
\hline $\begin{array}{l}\text { 肺高血圧合併 } \\
\text { 閉鎖方法 }\end{array}$ & $\begin{array}{c}1 \text { 例 }(7 \%) \\
\text { 直接閉鎖：14 例 } \\
\text { パッチ閉鎖：1 例 }\end{array}$ & $\begin{array}{c}1 \text { 例 }(4 \%) \\
\text { 直接閉鎖：27 例 }\end{array}$ & n.s. & $\begin{array}{c}1 \text { 例 }(17 \%) \\
\text { パッチ閉鎖：6 例 }\end{array}$ & $\begin{array}{c}28 \text { 例 }(68 \%) \\
\text { パッチ閉鎖：41 例 }\end{array}$ & $p<0.05$ \\
\hline 合併症 & なし & なし & & なし & $\begin{array}{l}\text { 一過性の } \\
\text { 痤攣発作（1 例） }\end{array}$ & \\
\hline
\end{tabular}

胸骨全正中切開に術中移行した症例は 1 例も認めず.

I 型：subarterial type, II 型：perimembranous type. 

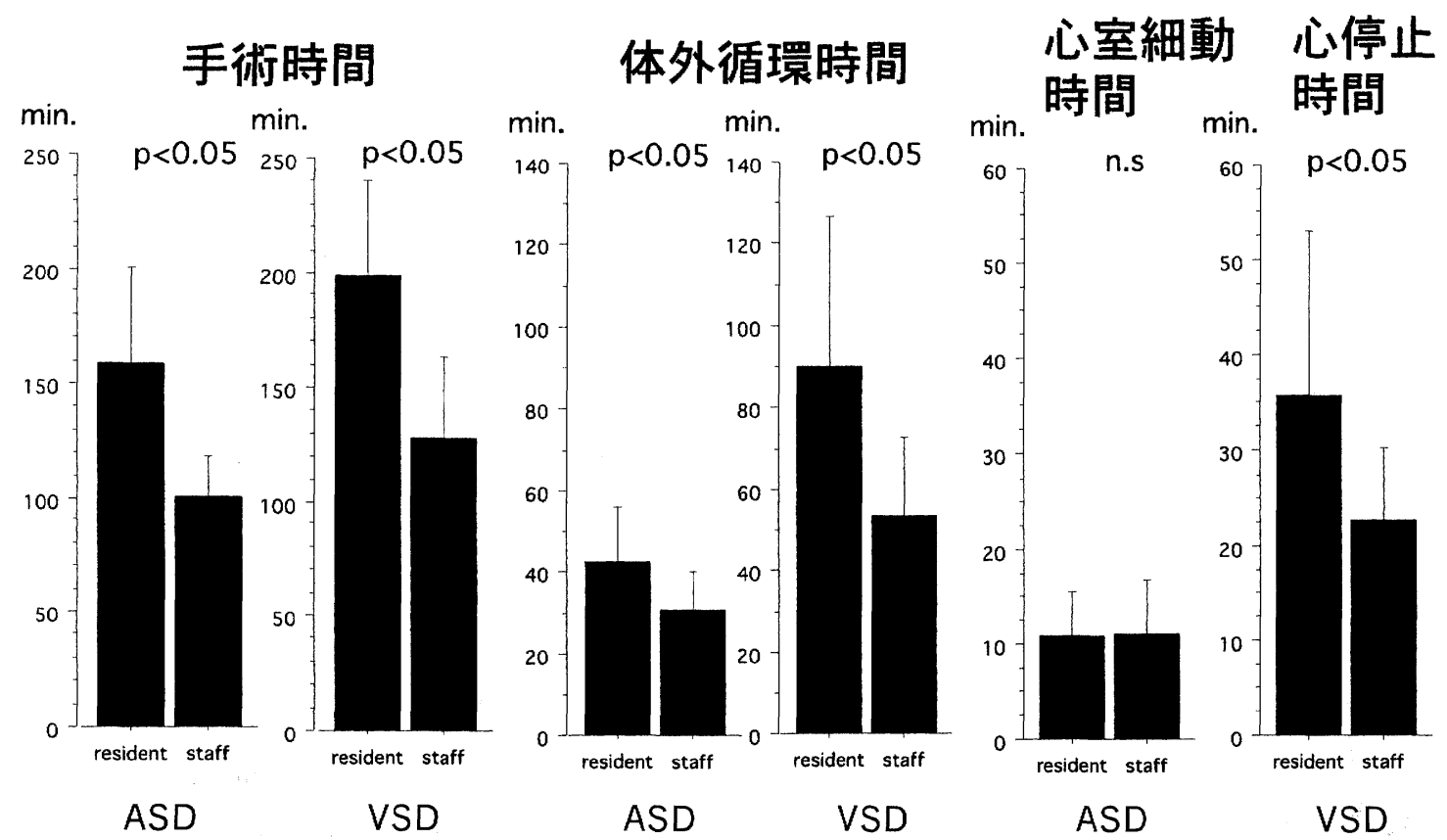

図 1 レジデント群とスタッフ群の比較 (1)

\section{術後挿管時間}

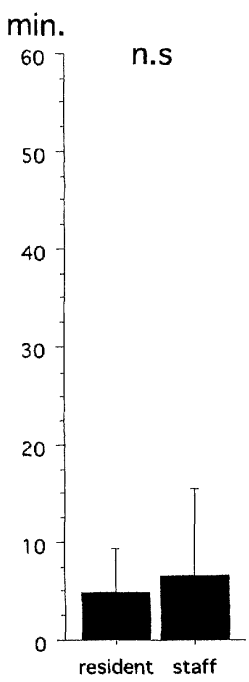

ASD

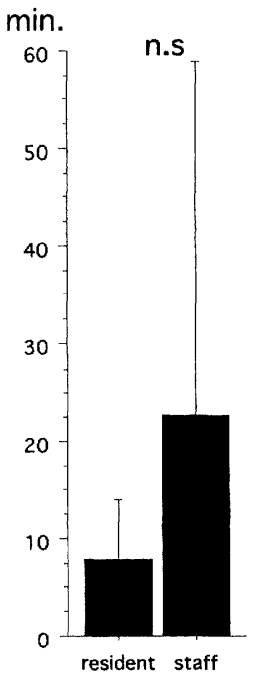

VSD
ICU 滞在日数

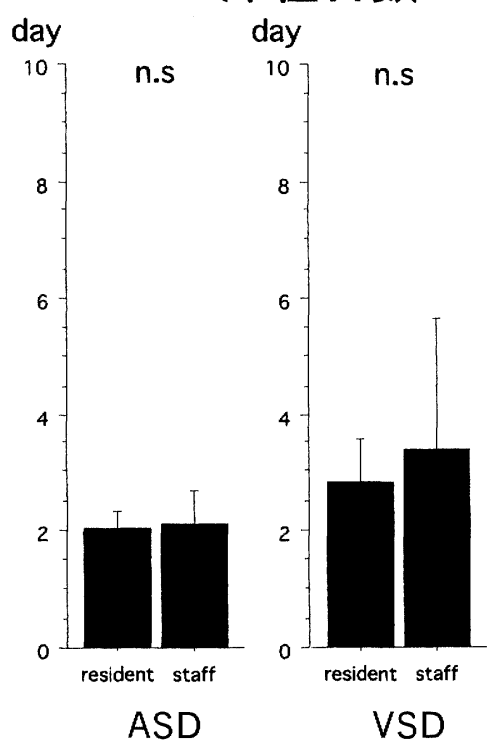

術後入院日数

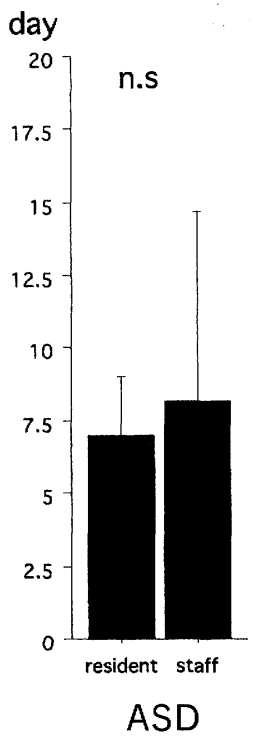

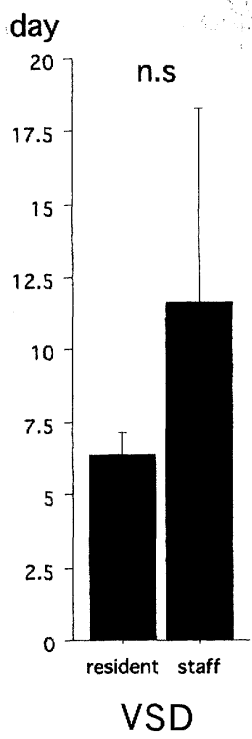

図 2 レジデント群とスタッフ群の比較 (2)

手術は通常の手術に比べて手技が困難になる傾向にあるた め, 今後標準術式として確立するか, レジデントの教育は どうするか，といった点が問題となってくる，そこで今回 は手術に関連する因子のレジデント群とスタッフ群の差を 検討することにより今後標準術式となりうるかについて検 討した。

スタッフ群の症例だけでなくレジデント群の ASD 15
例，VSD 6 例の全症例が MICS にて施行可能で胸骨全正 中切開にコンバートした症例は 1 例もなかった。合併症は スタッフ群の 1 例のみに認められ, レジデント群では 1 例 も認められなかった。対象患者はス夕ッフ群がやや体が小 さく，低年齢である傾向があったが，有意差はなかった。 ただし, レジデント群で肺高血圧症例が有意に少なく, 乳 児の肺高血圧症例がなかったことを考えると，このような 


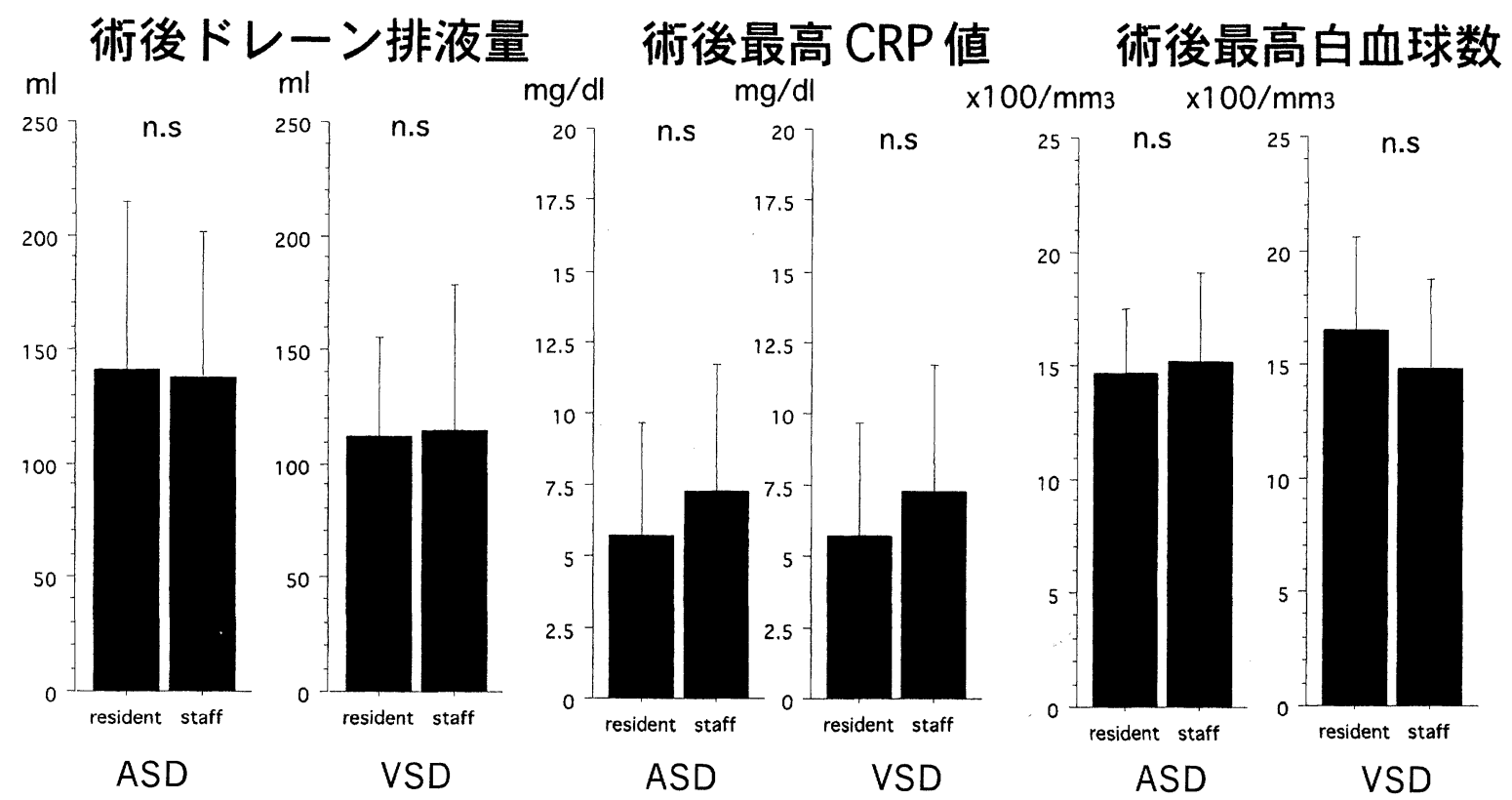

図 3 レジデント群とスタッフ群の比較 ( 3 )
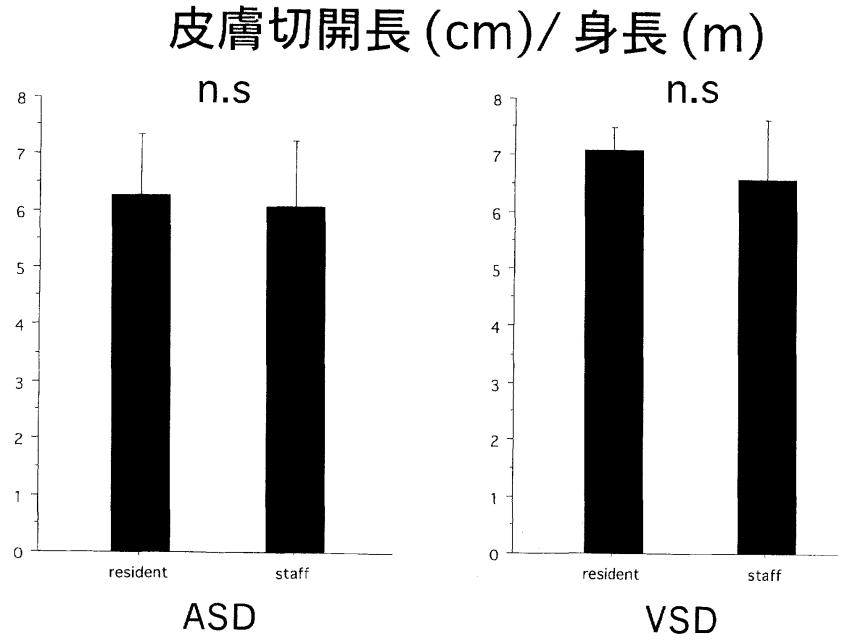

図 4 レジデント群とスタッフ群の比較 (4)

症例に対する適応は慎重にするべきだと思われた。以上よ り MICS 施行に関しては，一部の症例を除けば，十分な 修練をつんだスタッフの介助のもとレジデントでも十分に 可能であると考えられた。

手術時間，体外循環時間，心停止時間といった時間に関 する因子はスタッフ群が有意にレジデント群より短くなっ ており，八田ら ${ }^{8)}$ の ASD, VSD に扔ける報告と同様の結 果となっている．経験の浅いレジデントが手術時間が長く なることは一般的なことであり，このことが MICS が標 準術式として不適切ということにはならない.

最も重要な点は, 患者に対する手術の安全性と quality
の低下をもたらしてはならないということである，今回検 討した手術の侵襲度や患者に対する手術のqualityを反映

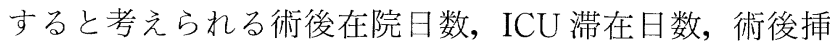
管時間, 術後ドレーン排液量, 術後最高白血球数, 術後最 高 CRP 值に関しては両群間に有意差を認めなかった。ま た, 小切開, 胸骨部分正中切開による MICS の最大の利 点である美容上での効果についても, 皮膚切開長 $(\mathrm{cm}) /$ 身長（m）は両群間で有意差を認めず，レジデント群が施 行することにより皮膚切開長が長くなることはなかった。 以上より, MICS をレジデントが施行することによる患者 に対する明らかな不利益汁認められないと考えられた。

近年の体外循環や心筋保護法などの画期的進歩により, ASD やVSDの安全性は確立されて抢り，これからは手 術成績や合併症について議論する時代からいかに患者の QOL を高めるかを議論する時代となってくる. 。 とくに幼 少時の手術創が患者に与える影響は強く，術後の手術創を

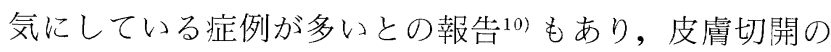
縮小化は患者の QOL 向上に不可欠なことである。いっ溧 うで，小切開アプローチにすることにより，従来の術式の 安全性や quality が損なわれることがあってはならない. そういった点からも，さまざまな小切開アプローチのなか で, 通常の胸骨正中切開にも簡単に移行可能で, 美容上の 十分な満足が得られ, 特別な器具を必要としない本術式は 有用な方法である。今回の検討により，一部の症例を除け ばレジデントにも十分施行可能で従来の術式と同様の quality を提供できる本術式の重要性は今後ますます高 まっていくものと思われる. 


\section{結語}

小正中皮膚切開，胸骨部分正中切開による MICSにて 施行される ASD, VSD は，一部の症例を除き十分に修練 を積んだスタッフの指導のもとで，レジデントでも施行可 能であった。また，時間因子以外は術者による術後経過の 差を認めず，患者に対する不利益は認められなかった，以 上より, 患者 $\mathrm{QOL}$ 向上の点で有用な本術式の今後標準術 式になる可能性が示唆された。

\section{文献}

1) Komai, H., Naito, Y., Fujiwara, K. et al.: Lower midline skin incision and minimal sternotomy: a more cosmetic challenge for pediatric cardiac surgery. Cardiol. Young. 6: 76-79, 1996.

2) Subramanian, V.A., Sani, G., Benetti, F. J. et al. : Minimally invasive direct coronary bypass surgery : a multi-center report of preliminary clinical experience. Circulation 92 (Suppl. 1) : 645, 1995.

3) Grinda, J. M., Folliguet, T. A., Dervanian, P. et al. :
Right anterolateral thoracotomy for repair of atrial septal defect. Ann. Thorac. Surg. 62 : 175-178, 1996.

4) Burke, R. P., Wernovsky, G., van der Verde, M. et al.: Video-assisted thoracoscopic surgery for congenital heart disease. J. Thorac. Cardiovasc. Surg. 109: 499508, 1995

5）四津良平，申範圭，前原正明注加：低侵襲心㵴手術 （MICS）に扔ける基本的アプローチとその選択．日外会誌 99: 810-816, 1998

6) Brutel de la Riviere, A., Brom, G. H. M. and Brom, A. C. : Horizontal submammary skin incision for median sternotomy. Ann. Thorac. Surg. 32 : 101-104, 1981.

7）西宏之, 西垣恭一, 久米庸一棌：先天性心疾患核対する 小皮膚切開, 胸骨部分切開に上る開心術. 日外連合会誌 25 ： 607-611, 2000.

8）八田英一郎, 村下十志文, 今村道明注か：先天性心疾患開心 術に対する Minimal access 手術は標準術式となりうる か？日心外会誌 29 (Suppl.)：164, 2000.

9) Murphy, J. G. : Long-term outcome after surgical repair of isolated atrial septal defect: Follow-up at 27 to 32 year. N. Eng. J. Med. 323: 1645-1650, 1990.

10）駒井宏好，内滕泰顯：心臟手術氾抢引る縮小胸骨正中切開 法. 日本醫事新報 3873: 34-36, 1998. 